\title{
Depopulation tendencies and territorial development in Lithuania
}

Vidmantas Daugirdas The depopulation process in Lithuania is rapid, Lithuanian Social Research Centre and the gap between the centre and periphery Institute of Human Geography in the country is increasing, which allows one and Demography, region to grow and others to 'fight' for survival.

Lithuania The main demographic indicators show

E-mail: particularly unfavourable trends in sparsely vidmantas.geo@gmail.com populated territories (SPTs) and deviate markedly from the countrywide average.

Gintarè Pociūtè-Sereikienè To confirm these statements, this study Lithuanian Social Research Centre presents the changes in the demographic and Institute of Human Geography and socioeconomic situation in Lithuania during

Demography, the period of restored independence.

Lithuania The authors place special emphasis on rural

E-mail: gintarei.pociutei@gmail.com SPTs of the country, and use statistical data as the main instrument to present the tendencies of sociospatial development. The analysis shows that Lithuania is experiencing territorial polarisation, with the greatest gap being between the major cities and the regions in Southern and North-Eastern Lithuania. Additionally, the results indicate that in the meantime, the western and central regions became the 'generators' of demographic and socioeconomic problems due to increasing depopulation. The sharpest results of depopulation are the decline of social networks and, simultaneously, the growing number of social problems. This situation increases

Keywords: residents' social and territorial exclusion, depopulation, meaning that institutions are receding from socioeconomic decline, those who remain in rural peripheral regions, sparsely populated territories, leaving them to fight the consequences of peripheralisation, peripheralisation alone without any clear Lithuania regional policy strategies. 


\section{Introduction}

Analysing demographic trends in Europe over the past twenty years shows that the European countries have a balanced demographic development pattern, almost without a natural change in population. Some countries, such as Germany, Italy, Russia, Scandinavian countries, or Austria (Dax-Fischer 2018) used to compensate for the loss of residents by accepting immigration. Today, the issue of immigration is rather complicated, and the 'welcoming countries' are regulating immigration more strictly. Despite the examples of countries with growing populations, many European countries, and especially their rural territories, are experiencing demographic decline (Copus et al. 2011). The phenomenon of demographic, social, and economic decline and increasing inequality is especially evident in Central and Eastern European (CEE) countries (Kühn 2013, Kühn-Bernt 2013, Lang 2015, Leick-Lang 2018, Nagy-Nagy-Dudás 2016, Nemes Nagy-Tagai 2011, Smętkowski 2018, Kovács-Bodnár 2017, Ilcsikné Makra et al. 2018). Leick and Lang $(2018$, p. 214 .) stress that ' $\ldots$..complex economic-social-demographic dilemmas shape the future of regional economic development in these cases (bearing in mind CEE countries [the authors' supplement]), implying persistent, and mutually selfreinforcing, processes of social and economic marginalization, spatial, political and discursive peripheralization (...), and even stigmatization (...).' Therefore, depopulation in Lithuania is not unique, but rather part of a general phenomenon of territorial polarisation and depopulation in CEE. Due to historical circumstances, the CEE region is unique in the European context, with a significant influence on the current demographic and socioeconomic situation (Krisjane 2001; Nagy 2005, 2010). The essential political, economic, and social transformation from a planned to market economy in the early 1990s changed the demographic structure considerably due to decreasing birth rates, ageing, and growing out-migration (Bernt et al. 2012, Philipov-Kohler 2001, Sobotka et al. 2003). The demographic changes and growing problems in CEE countries occurred in all territorial units, but with growing inequality between the centres and peripheries (Raagmaa 1996, 2003; Churski et al. 2014); and the changes affect peripheral rural territories the most (Amcoff-Westholm 2007, Kriaučiünas 2010). The rural areas that were home to many residents during the socialist period cannot offer jobs for all of its previous residents, keep the same standard of living, or provide the same infrastructure as before the 1990s; therefore, life in rural areas no longer satisfies residents (Pociūté-Sereikienè et al. 2014). However, the process of depopulation and changes in the network of settlements in post-socialist countries were not unexpected and stand as natural processes arising due to the collapse of the Soviet Union.

The depopulation process in Lithuania is rapid, and the gap between the centre and periphery in the country is increasing, allowing one region to grow and others to 'fight' for survival (Ubarevičiené-van Ham 2017). The three biggest cities in

Regional Statistics, Vol. 8. No. 2. 2018: 46-68; DOI: 10.15196/RS080203 
Lithuania - Vilnius, Kaunas, and Klaipéda - stand as national centres (Burneika et al. 2017) and compete on a global scale; the other bigger Lithuanian cities - Siauliai, Panevéžys, and Alytus - function as regional centres, which are essential for inner Lithuanian territories (Pociūté 2014). Meanwhile, the rural territories are rapidly depopulating, leaving several socioeconomic problems for the remaining residents in the region to face (Daugirdas et al. 2013, Kriaučiūnas 2010, Kriaučiūnas et al. 2014, Pociūté-Sereikiené et al. 2014). Despite the number of previous studies, we still lack information about the territorial differences in depopulation in Lithuania. There is still a great need to research sparsely populated and problem regions (SPRs) that are closely connected with increasing disparities in quality of life, welfare, and territorial exclusion in the country. Research examining the topic of polarisation and the expansion of SPTs that study Lithuania is lacking in the scholarly literature. With this study, we aim to discuss the changes that occurred within Lithuania in detail, with a focus on the lower regional scale areas (LAU 1 units) of the country.

This study presents the changes in the demographic and socioeconomic situation in Lithuania during the period of restored independence, focusing on the SPTs of the country. It is an analytical work that is rather data-driven and based on an analysis of statistical information.

We start with a methodological section in which we define the problem of SPTs and explain the process of socioeconomic exclusion in depopulating and lagging regions. Furthermore, we discuss the general demographic and social tendencies in the country, with a focus on SPTs. The results section presents a summary of the demographic and socioeconomic changes and increasing polarisation in Lithuania during the last ten years, while pointing out the 'weakest' regions. We end the article with concluding remarks, wherein we summarise our observations and discuss the prospects of depopulating territories.

\section{Methodological background}

\section{Understanding the problem of SPTs}

The spread of SPTs has become a serious challenge for CEE societies. Even special regional policies or subsidies for SPTs do not help to keep inhabitants in depopulating regions (Copus-Dax 2010, Jauhiainen 2000, Gløersen et al. 2009). The dispersion of sparsely populated areas has direct links with depopulation tendencies and the decrease in the average population density. However, the problem of increasing SPTs is not new, especially in Northern European countries, whose main feature is low population density in peripheral territories (Gløersen et al. 2006, 2009). Another example of SPTs is the Aragón region (Comunidad Autónoma de Aragón) in Spain, one of the most sparsely populated regions in Europe (Escalona-Orcao-Díez-Cornago 2007). Bulgaria is another

Regional Statistics, Vol. 8. No. 2. 2018:46-68; DOI: 10.15196/RS080203 
country suffering from intensive depopulation (Mladenov-Ilieva 2012). Mladenov and Ilieva (2012) point out that depopulation in Bulgaria hit mountainous and border villages the most. Dozens of villages were excluded from the national settlement registry ${ }^{1}$ in Bulgaria. These are only a few examples, but we might find SPTs in many more countries, too. In the countries in which SPTs are spreading, similar problems arise: increasing depopulation, youth emigration, unemployment, deterioration of infrastructure, and decrease in the number of enterprises and social facilities (Daugirdas et al. 2013, Escalona-Orcao-Díez-Cornago 2007, Gløersen et al. 2006, Mladenov-Ilieva 2012). These characteristics make younger residents unwilling to settle in peripheral rural territories. The European Union (EU) regional policy documents (Margaras 2016, NSPA 2009, European Commission 2004, etc.) and other scientific publications (for example, Daugirdas et al. 2013; EscalonaOrcao-Díez-Cornago 2007; Gløersen et al. 2005, 2006, 2009; ADE 2012; Zasada et al. 2013) define SPTs as territories whose population density ranges between 5 and 60 inhabitants per square kilometre. Following this definition, in most cases (except for cities), Lithuania could be considered a sparsely populated country (its average population density at the beginning of 2018 was only 43 inhabitants per square kilometre). Therefore, we suggest that while analysing SPTs, we ought to pay the greatest attention to the most sparsely populated areas (Daugirdas et al. 2013). For instance, we can take Northern countries as an example, where SPTs have population densities below 8-12.5 inhabitants per square kilometre (NSPA 2009). When identifying SPTs in the Northern countries, scholars also consider the dimension of the sparseness of settlements' net and social infrastructure, which has a close connection with the distribution of inhabitants: 'Sparsity characterises regions where extremely low population densities and dispersed settlement patterns create specific challenges for economic activity and public service provision. In other words, low regional population densities are not sufficient to characterise a region as "sparse". Sparsity occurs insofar as the combination of low population densities and dispersed settlement patterns lead to specific challenges for economic activity.' (Gløersen et al. 2005, p. 3.).

The Third Report on Economic and Social Cohesion (European Commission 2004, p. 30.) emphasises that SPTs are frequently located in outlying territories: '...peripheral areas, far from urban centres and main transport networks. Their isolation is often due to their topographical features (such as a mountain range) and they tend to have an ageing population, poor infrastructure endowment, a low level of basic services and income per head, a poorly qualified work force, and to be not well integrated into the global economy.' We could accept this description for Lithuania as well, but instead of mountain chains, we need to pay attention to

${ }^{1}$ Based on data from the last census of Lithuania, 4,201 settlements in Lithuania did not have any residents in 2011 (Statistics Lithuania 2018).

Regional Statistics, Vol. 8. No. 2. 2018: 46-68; DOI: 10.15196/RS080203 
soil fertility, forests, and lakes because these are the essential factors for the appearance of SPTs in the country.

In Lithuania, we define SPTs as territories whose rural population density is below 12.5 inhabitants per square kilometre (Daugirdas et al. 2013). More than fifteen years ago, when we began to research this topic, there were only a few SPTs in the country (see Figure 6). Since the beginning of our research, we have focused on the average density of the rural population in the most sparsely populated municipalities (SPMs). We have maintained this research line to compare new and old data and to observe the changes in SPTs in Lithuania.

We divide the results of this study into two parts: 1. a general analysis of the change in demographic and social indicators and the summary of the calculations of demographic and socioeconomic indicators; 2. a discussion of the municipalities that are experiencing demographic and socioeconomic decline. Furthermore, we present the methodology underlying these calculations.

\section{Determination of depopulation and regions that lag socioeconomically}

The study follows a quantitative research methodology with a special emphasis on analysing selected statistical indicators. For this analysis, we use statistics collected from the Statistics Lithuania database (2018). To better uncover the territorial differences, we examine the municipal ${ }^{2}$ level. However, our selection of indicators was restricted by the ability to access data at the municipal scale.

For our analysis, we use a methodology adapted from a defended $\mathrm{PhD}$ thesis (Pociūté 2014). The aim of the research is to point out the 'weakest' municipalities by clustering them into groups according to the deviation from the Lithuanian average. This work is performed while analysing a wide range of demographic and socioeconomic statistical indicators ${ }^{3}$. We chose these research dimensions because the demographic changes in the analysed regions are accompanied by socioeconomic underdevelopment. We selected the 2006-2016 period for the analysis to show the changes taken place in the country in a ten-year period. Since the latest social statistical data are from 2016, it was selected as the final year to be examined. We composed the matrix of indicators according to the academic literature and indicators presented by scholars (Copus 2001; Dax-Fischer 2018; Gutiérrez-Urbano 1996; Haase et al. 2014; Janc 2006; Marada et al. 2006; MisiūnasSvetikas 2003; Nagy 2005, 2010; Smętkowski 2018; Vaishar 2006) and legal

\footnotetext{
${ }^{2}$ According to the European statistical system (Eurostat), Lithuania is divided into several territorial levels: 10 regions as NUT 3 (in Lithuanian apskritys), 60 as LAU 1 (municipalities [savivaldybeis]), and around 500 as LAU 2 (wards [seniünijos]).

${ }^{3}$ The following indicators were selected for the analysis: 1. demographic indicators: population density, natural change, net migration, ageing index; 2. socioeconomic indicators: unemployment rate, proportion between recipients of social assistance benefits and all population, gross earnings, school network density, foreign direct investment, number of newly built apartments.
}

Regional Statistics, Vol. 8. No. 2. 2018:46-68; DOI: 10.15196/RS080203 
documents from the government of Lithuania (LR Vyriausybés 2003, National Regional Development Council 2017). We primarily focused on Pociūté's (2014) research and selected indicators. This work allowed us to choose demographic and socioeconomic indicators that best emphasise the regional differences in Lithuania. However, regional disparities may be studied in other ways too. With this study, we do not intend to point out that our evaluation is better than others are, but rather to provide a different approach to evaluation and present one more way to calculate and address the increasing polarisation of the country. We understand that the system of the selected indicators is rather subjective and greatly depends on our decisions as researchers to underline one issue or another.

To highlight the most prosperous, intermediate, and lagging territories, we divided municipalities into groups according to the deviation of their statistical indicators from the country's average (see Figure 1a), by equating the Lithuanian average to $0 \%$. By the calculated percentage deviation from the Lithuanian average $(0 \%)$, we classified all 60 municipalities of Lithuania into five groups. According to the resolution of the Government of the Republic of Lithuania (LR Vyriausybés 2003) and due to the desire to separate particularly lagging territories, we chose $\pm 60 \%$ as critical margins for the most prosperous/troubled municipalities and $\pm 20 \%$ margins for municipalities that were closest to the national average (both above and below average). Furthermore, two groups lay between the two types of margin points (from $20 \%$ to $60 \%$ and from $-20 \%$ to $-60 \%$ ). In our case, we paid attention to two clustered groups of municipalities: those with the lowest indicator values (from $-20 \%$ to $-60 \%$ and below $-60 \%$, marked in darker and lighter orange in Figure 1a). We can thus determine the municipalities that are lagging the most.

After clustering municipalities into groups, we evaluated the two groups with the most negative indicator values (in points, see Figure $1 \mathrm{~b}$ ). Then we calculated the total points for both analysed years (2006 and 2016) and the cumulative average points (see Figure 1c). In order to examine only the municipalities with long-lasting problems, we gave points only to those municipalities that were clustered into the two excluded groups in 2006 and 2016. In the map presented in the results section (see Figure 9), we can see the municipalities having 1 to 2 cumulative average points; 2 is the maximum number of points showing the 'most negative' situation. Based on the cumulative average points, we can determine which regions are socioeconomically disadvantaged and depopulating the fastest (see Figure 1d).

Regional Statistics, Vol. 8. No. 2. 2018: 46-68; DOI: 10.15196/RS080203 
Figure 1

Algorithm dividing Lithuanian municipalities (LAU 1) into clusters according to demographic and socioeconomic indicators

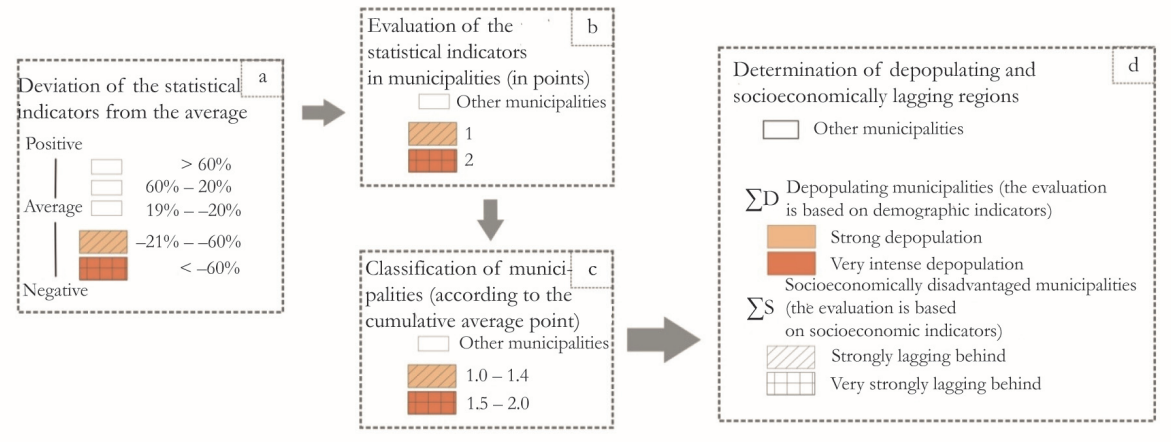

\section{The trends in demographic changes in Lithuania}

The depopulation in Lithuania started with the restoration of independence in the 1990s (Burneika 2012, Kriaučiūnas et al. 2014, Pociūté-Sereikienè et al. 2014). However, the depopulation tendency emerged particularly after Lithuania's accession to the EU in 2004 (mainly due to the increase in emigration) (Kriaučiūnas 2010, Statistics Lithuania 2018). Sadly, one of the highest rates of depopulation in the EU remains in Lithuania: the decrease in residents was $2.7 \%$ in $2010,1.4 \%$ in 2016 and 1.3\% in 2017 (Eurostat database 2018). The causes of depopulation are apparent and similar to those of other countries: intensive emigration, low birth rates, and population ageing (Haase et al. 2014, Janc 2006, Kulcsár-Brown 2017, Pociūté 2014, Smętkowski 2018). Lithuania is experiencing a demographic crisis. The result of this rapid depopulation is that the Lithuanian population in the last 25 years decreased by about 25\%. According to Statistics Lithuania data (2018), $2,810,118$ inhabitants lived in the country at the beginning of 2018, while in 1992, Lithuania had 3,746,400 residents (see Figure 2).

The demographic situation in the cities (except the capital, Vilnius) of Lithuania is declining and therefore similar to that in rural territories. The major difference between the shrinkage of rural and urban population is the reasons for the shrinkage. In the cities, the shrinkage is due first to emigration and suburbanisation. However, the population is growing in three exceptional municipalities in Lithuania: the Vilnius, Kaunas, and Klaipéda districts' municipalities (Burneika et al. 2017). These municipalities are growing at the expense of cities mostly due to the suburbanisation processes.

We can expect that the population will grow in and around metropolitan cities, but in SPTs and SPRs, it is hard to expect positive changes (Daugirdas et al. 2013).

Regional Statistics, Vol. 8. No. 2. 2018:46-68; DOI: 10.15196/RS080203 
There are two main reasons why we cannot expect population growth in peripheral areas in the near future: low birth rates and high emigration. According to official statistics (Statistics Lithuania 2018), natural reproduction in Lithuania has been negative for more than 20 years (see Figure 2). Therefore, all of Lithuania has very low fertility rates, especially in peripheral sparsely populated areas. In 2017, the birth rate was only $10.5 \%$, and the rate of natural population increase was $-3.5 \%$ in the country.

Figure 2

\section{Decrease in Lithuanian population and fluctuation of the rate of natural population change}

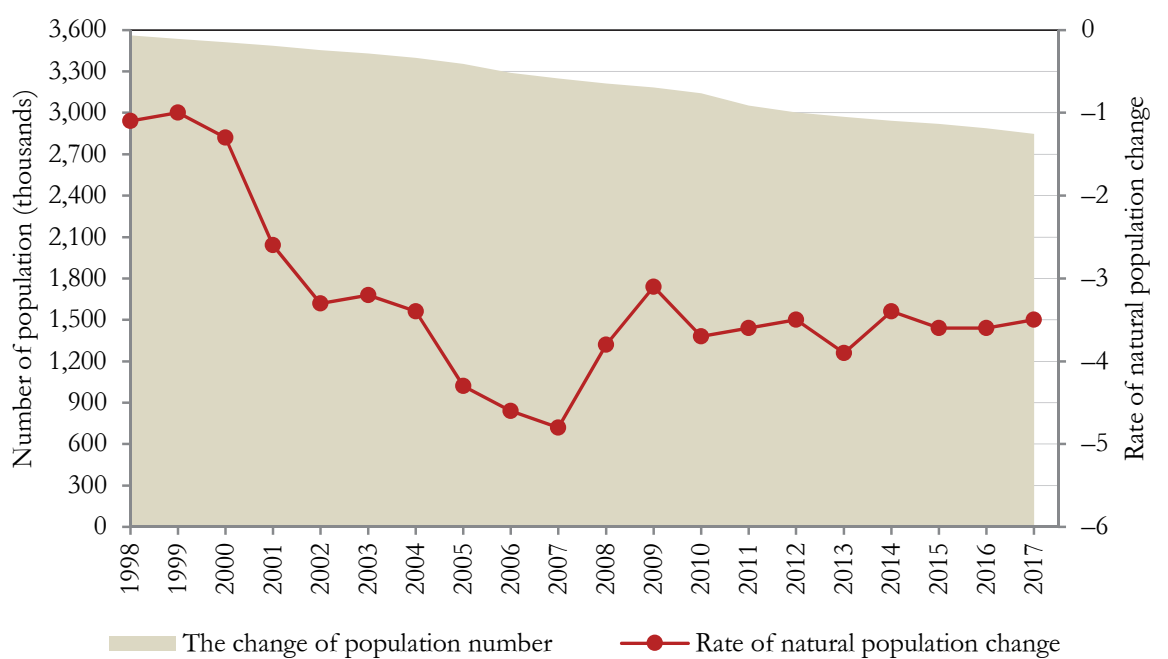

Source: Statistics Lithuania (2018).

The scale of emigration fluctuates but remains high. Last year, around 57,300 residents emigrated from Lithuania, while around 29,300 people returned or immigrated to the country (see Figure 3). Between 2001 and 2017, 699,124 residents left Lithuania, 109,243 (15.6\%) of them were from SPMs (Statistics Lithuania 2018). During the same period, 217,691 residents immigrated to Lithuania, of which 27,460 (12.6\%) moved to live in SPMs (Statistics Lithuania 2018). Due to such high emigration and low immigration, the phenomenon of migration plays a major role in depopulation. In recent years, the rate of net international migration has slightly increased due to the growing number of immigrants; however, we note that very few people are returning to declining rural peripheral regions.

Regional Statistics, Vol. 8. No. 2. 2018: 46-68; DOI: 10.15196/RS080203 
International net migration and immigrants in Lithuania

Figure 3

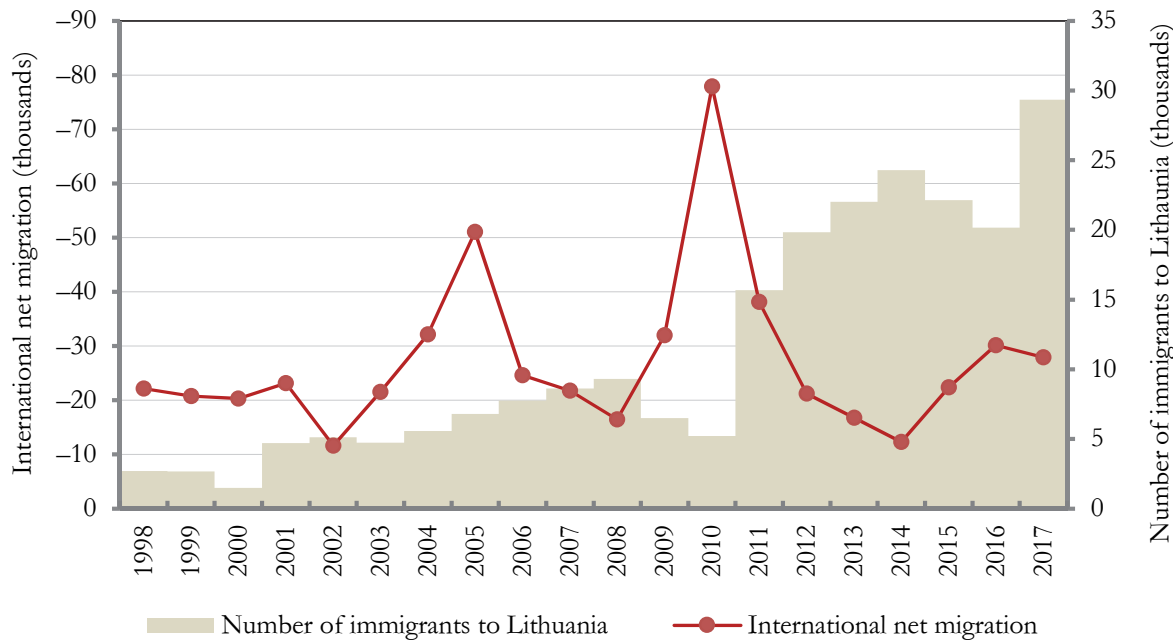

Source: Statistics Lithuania (2018).

\section{Population ageing}

Due to negative net migration and low fertility rates, Lithuania has a fast-growing population-ageing index ${ }^{4}$ (for more about population ageing in Eastern Europe, including Lithuania, see Kulcsár-Brown 2017). In 2001, this index was 71; in 2017, it reached 130, meaning that it has nearly doubled.

Territorial differences in the population ageing of Lithuania are also high. The highest ageing indexes are in North-Eastern and Southern Lithuania (see Figure 4), which regions are the most sparsely populated (see Figure 6). In some municipalities in SPRs, the index is twice that of the Lithuanian average. For instance, in Ignalina municipality (North-Eastern Lithuania), the ageing index was 239 (the Lithuanian average was 129), the population density was 11.3 people per square kilometre (the Lithuanian average was 44.2), and the natural change was -14.4 (the Lithuanian average was -3.6) in 2016.

If we look at the ageing tendencies illustrated in the grayscale picture on the right of Figure 4, we see the rapid ageing in Western and Northern Lithuania and in some urban municipalities (such as Visaginas, Alytus, and Panevéžys), where the index approximately doubled. When Lithuania regained independence in 1990, the number of children and young people was the highest in Western Lithuania, and it was a 'baby-boom' period in that area. By the beginning of the $21^{\text {st }}$ century, these

\footnotetext{
2018).

${ }^{4}$ Number of elderly people (65 years and older) per 100 children under the age of 15 (Statistics Lithuania
}

Regional Statistics, Vol. 8. No. 2. 2018:46-68; DOI: 10.15196/RS080203 
kids had finished primary and/or secondary school and due to the lack of workplaces, left the western municipalities and moved to major cities or abroad (Kriaučiūnas 2010), expecting to create a better life 'somewhere else', leaving 'lessmobile' older people in the rural regions.

\section{Population ageing in Lithuanian municipalities}

Figure 4
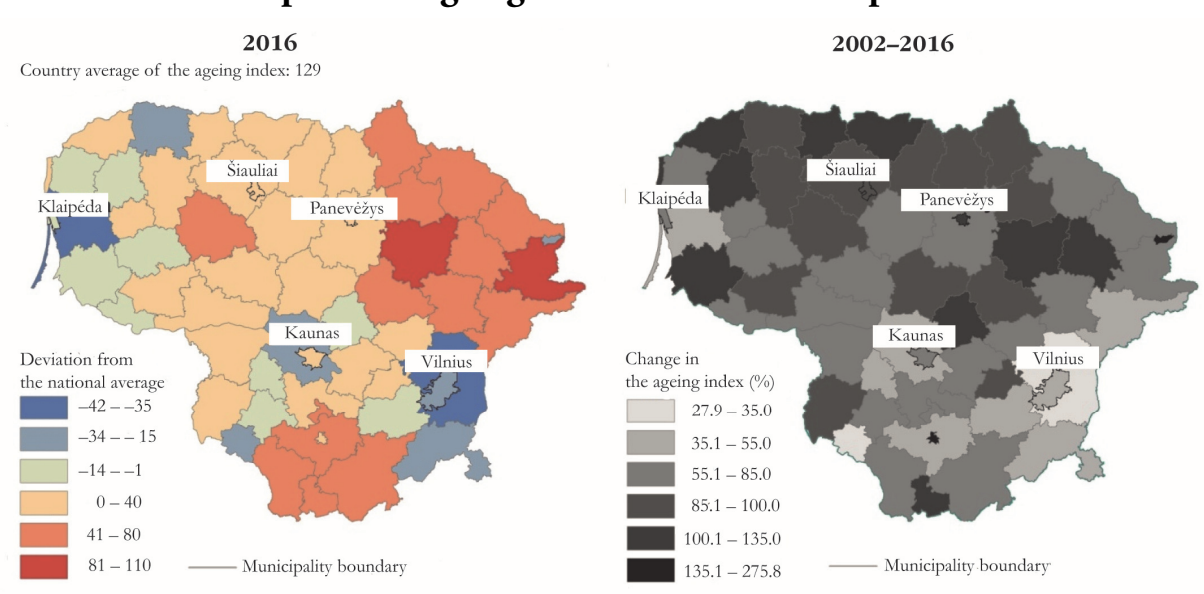

Source: Statistics Lithuania (2018). Graphics: Aušra Baranauskaité.

\section{The influence of depopulation on the educational system}

The disappearance of the network of schools is most closely linked to the demographic situation. Therefore, here we use the change in the number of general schools as an indicator to illustrate the link between the demographic and socioeconomic situation and to discuss depopulation tendencies. To illustrate these connections, we can compare Figures 5 (picture on the left) and 6 (presenting data for 2018).

Statistics show that Lithuania has experienced a great decline of the education system (see Figure 5), which was mainly influenced by decline in the birth rate and emigration of young families (Sipavičiené-Stankūniené 2013, Stankūniené et al. 2012). Since 2001, the number of schools has decreased on average by $49.3 \%$ in the country, whereas in SPMs by $61.9 \%$. The number of pupils in general schools shows similar tendencies. Since 2001, it has fallen on average by $45.1 \%$ throughout the country, while in SPMs by 55.1\%. Most Lithuanian territories have experienced a $30-60 \%$ decline in the number of students. Due to strong depopulation, the municipalities of the southern and north-eastern regions have a very sparse school network that is still shrinking; for instance, in Varéna municipality, we counted 0.9 schools per 100 square kilometres in 2006 (the Lithuanian average was 2.3 at that time), while in 2016, the indicator was only 0.5 schools per 100 square kilometres (the Lithuanian average was 1.8). Consequently, due to the

Regional Statistics, Vol. 8. No. 2. 2018: 46-68; DOI: 10.15196/RS080203 
decreasing number of children, the network of schools is disappearing all around Lithuania, leaving Vilnius city as the exception.

The biggest problem is that after school closures, other key institutions for the settlements, such as cultural centres, kindergartens, libraries, medical centres, post offices, banking departments, and shops are also closing (Kriaučiūnas et al. 2014, Pociūté-Sereikiené et al. 2014). Public transport accessibility is decreasing as well. Schools are basic institutions, without which the territory becomes non-attractive for young families - and for others, too. Of course, some of the services can become mobile (e.g. shops or the postal service), but schools cannot become mobile; as they are getting more distant from many pupils' place of residence, territorial exclusion increases, and the quality of life decreases, which is closely connected with the peripheralisation tendencies in the country.

Change in the number of general schools and pupils in Lithuania, 2001-2016

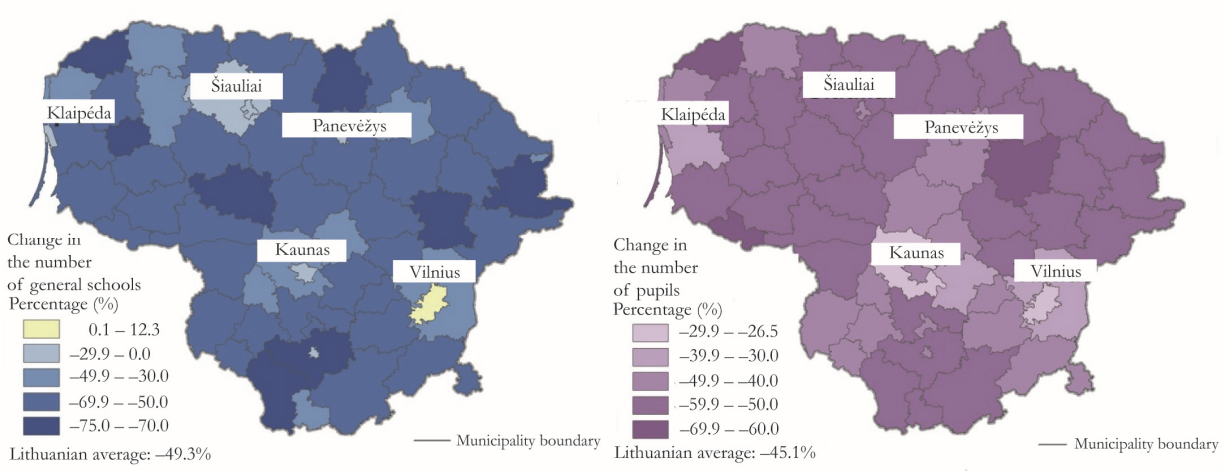

Source: Statistics Lithuania (2017), (2017). Graphics: Viktorija Baranauskiené.

\section{Expansion of SPTs in Lithuania}

Due to the negative demographic processes, we can see the formation and expansion of SPTs and SPRs (see Figure 6). The situation has substantially changed recently - SPTs has been already occupying around $45 \%$ of the territory of Lithuania. In 2018, (out of 60) 22 municipalities are sparsely populated, whereas in 2001 there were only seven such municipalities (see Figure 6). SPMs constitute large continuous regions in Lithuania. Therefore, an SPR should be defined as a large compound of SPTs characterised by not only demographic, but also specific socioeconomic behaviours and processes. North-Eastern Lithuania is the best example of the SPR phenomenon. In this part of Lithuania, 11 SPMs compose one solid region. However, similar groups of municipalities are already forming in Southern and Northern Lithuania (see Figure 6). In Lithuania, we find 14 municipalities in which the rural population does not reach 10 inhabitants per square kilometre.

Regional Statistics, Vol. 8. No. 2. 2018:46-68; DOI: 10.15196/RS080203 
Figure 6

\section{Sparsely populated municipalities in Lithuania}

2001

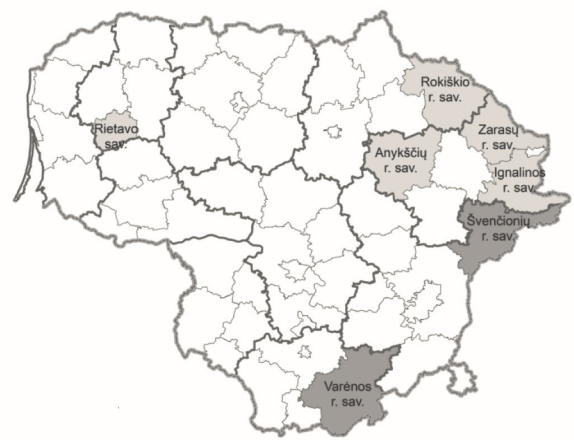

2018

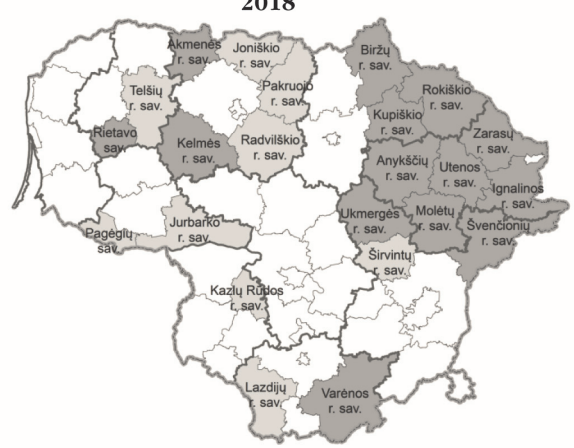

Note. r. sav. means district municipality.

Source: Statistics Lithuania (2018). Graphics: Viktorija Baranauskiené
2011

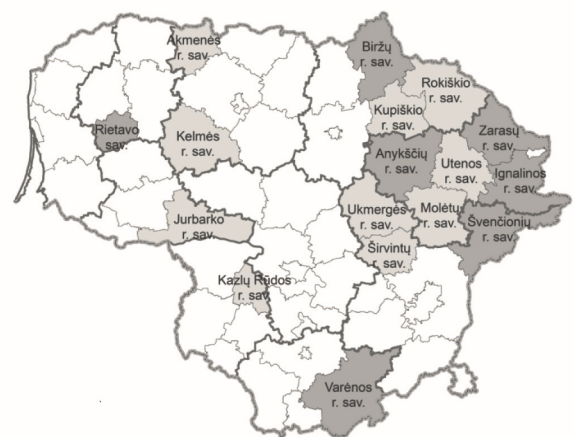

In some north-eastern municipalities (Ignalina, Biržai, Zarasai), the number of residents decreased by one-third during the last twenty years (Statistics Lithuania 2018). These municipalities are among territories with the lowest population numbers and densities in this region. The number of abandoned houses, schools, cultural centres, and other institutions is rapidly increasing (Kriaučiūnas et al. 2014) in the declining SPMs (see Figure 7). In general, villages in problem regions are mostly small and still shrinking and they have only a few inhabitants left. Depopulation in SPMs leads to the disappearance of the network of education (see Figure 5) and other social service institutions. From previous studies (Daugirdas et al. 2013) and discussions with local authorities, we note that the massive renovation of schools, roads, infrastructure, and other public facilities does not help to keep the balance in such municipalities. Thus, we often raise the question in discussions with local authorities: 'Is it worth investing in schools of declining regions?' (as these schools are eventually closed anyway).

Regional Statistics, Vol. 8. No. 2. 2018: 46-68; DOI: 10.15196/RS080203 
The responding officials usually answer that they understand the problem of depopulation, but they want to make their living places more beautiful and attractive for local residents and tourists (see Figure 8).

Figure 7

Abandoned houses in sparsely populated territories
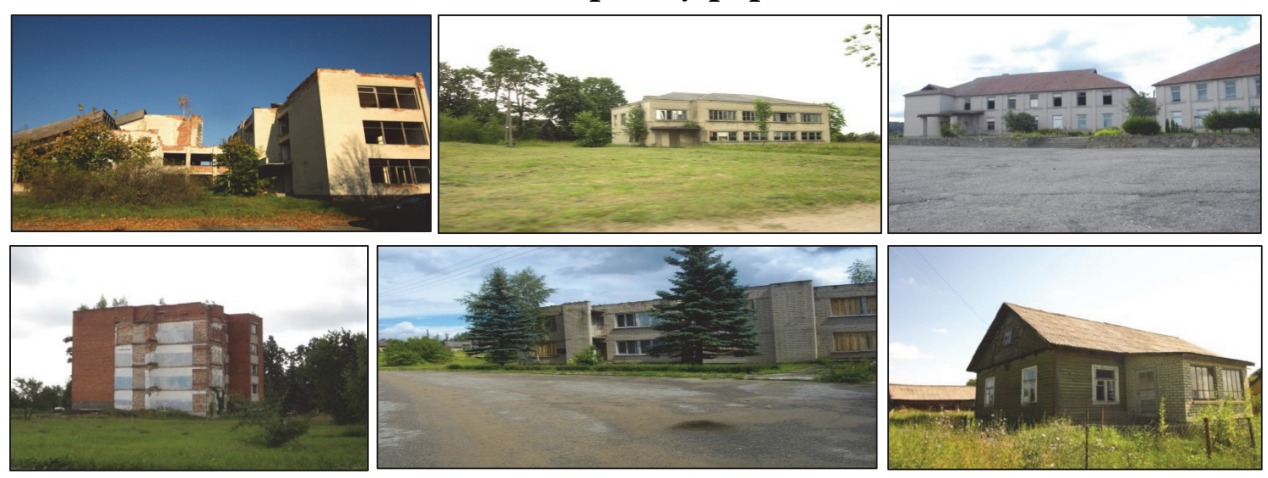

Photos: Gintarè Pociūtè-Sereikienè and Edis Kriaučiūnas.

Figure 8

Renovated houses in sparsely populated territories
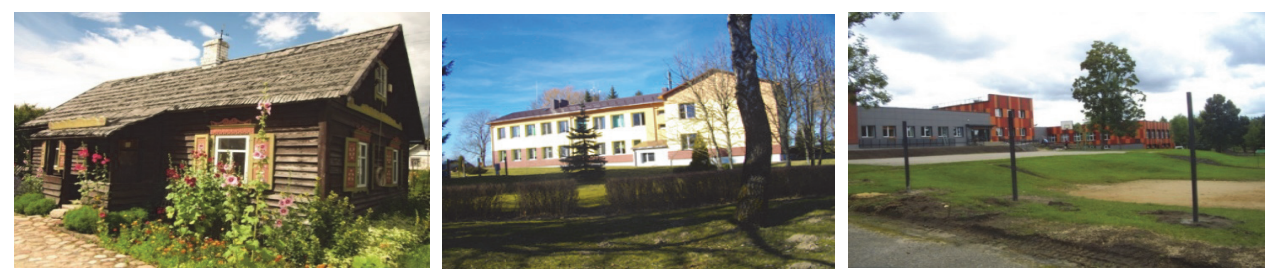

Photos: Gintarẻ Pociūtè-Sereikienè and Edis Kriaučiūnas.

\section{Depopulation and socioeconomic decline in LAU 1 regions in Lithuania}

The analysis of demographic and socioeconomic indicators shows the picture of a 'divided' Lithuania (see Figure 9). In general, the western part of Lithuania and the municipalities around the major cities of the country have better indicators. These results indicate that cities are the engines of the region, and in this case, Lithuania 'wins' by having big enough cities spread across the country (the heritage of the settlement system planning from the Soviet period) (Vanagas et al. 2002). On the other hand, the most recent studies (Ubarevičiené-van Ham 2017) underline the rapid decline in regional cities that cannot compete internationally, and by comparing 2006 and 2016 statistics, we might presume that we will soon see more 'orange' municipalities in Figure 9. 
The calculations show that in the ten-year period, the most depopulating municipalities were in the southern and north-eastern parts of Lithuania (see Figure 9). These municipalities have the lowest population densities and are the 'oldest municipalities' with the worst indicators of natural change. They can be characterised by 'very intensive', long lasting depopulation (Daugirdas et al. 2013). However, in the southern and north-eastern municipalities, the net migration index is around the average because fewer people would like to emigrate from there (most of their population is old), and these regions are depopulating mostly due to strongly negative natural change. Meanwhile, in municipalities described by 'strong depopulation' in Figure 9, the population decline is largely influenced by a high emigration rate. According to 2016 data, the net migration indicator in most Western Lithuanian municipalities was smaller than $-20 \%$, (in Pagégiai municipality, the net migration indicator was $-30.5 \%$ ), whereas the average for Lithuania was $-10.5 \%$. Currently, these municipalities face great demographic problems and the fastest depopulation tendencies in the country.

Figure 9

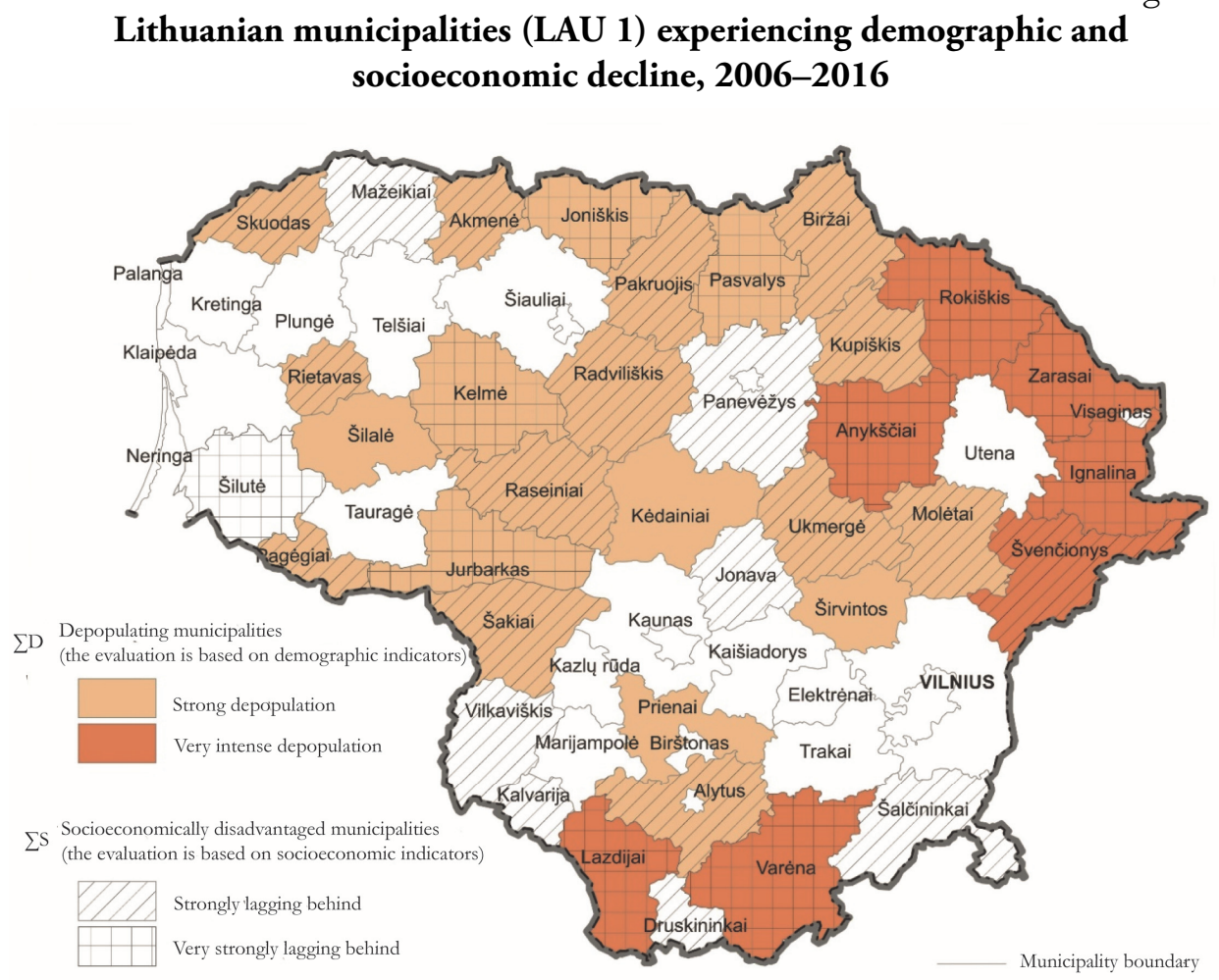

Source: Own elaboration based on Statistics Lithuania data.

Regional Statistics, Vol. 8. No. 2. 2018: 46-68; DOI: 10.15196/RS080203 
The analysis shows that the socioeconomically disadvantaged municipalities cover the depopulating regions (see Figures 6 and 9). Again, the southern and north-eastern regions are the most disadvantaged and very strongly lagging behind the economically strong centres. The municipalities of these regions are unattractive for foreign investors; for instance, Lazdijai did not receive any foreign direct investment in 2016.

The municipalities that were 'at the bottom of sequence' in 2006 in terms of unemployment rate, remained in the worst unemployment situation in 2016 as well. The figures allow us to examine long-lasting unemployment in North-Eastern Lithuania and the municipalities of the central and western parts of the country, wherein the unemployment rate is almost twice as high as that of the Lithuanian average. The ratio of the recipients of social assistance benefits to the total population in Lithuania has nearly tripled in ten years: it increased from 1.1 in 2006 to 3.1 in 2016. This indicator is closely connected with the unemployment rate, and we therefore find high values for the most disadvantaged municipalities in the southern and north-eastern regions and around the border. For instance, in Kalvarija municipality in Southern Lithuania, the indicator increased more than five times, from 2.2 to 9.2 , from 2006 to 2016.

Summarising the ten-year tendencies, we can say that great depopulation and increasing polarisation are going on in Lithuania. However, some regions are more at risk as generators of demographic problems. The western-central part of Lithuania is in the 'riskiest' position. The municipalities in these regions are currently coping with great depopulation mostly due to the emigration of the young generation (Kriaučiūnas 2010). These municipalities are 'donors' of workforce for the major cities and foreign countries. If we look at the indicators from a 20-year perspective, we can see an even greater loss of human capital. For instance, in Kelmé municipality of Central Lithuania (marked with 'strong depopulation'), the population density was 24.9 residents per square kilometre in 1996, while in 2016, it was only 16.8. In a 20 -year period, the municipality lost $34 \%$ of its residents. It is also one of the fastest ageing municipalities, where the ageing index was 103 in 1996, 118 in 2006, and 174 in 2016. High emigration from this municipality might be seen as one of the reasons for such fast ageing: the net migration rate was -3.5 (the Lithuanian average was -6.5) in 1996, -6.5 (the Lithuanian average was -1.4 ) in 2006, and -22.9 (the Lithuanian average was -10.5) in 2016. Kelmé municipality is just one of several rapidly depopulating municipalities in the westerncentral region of Lithuania.

The north-eastern and southern regions are 'very intensely depopulating', but their situation is different from that of the western-central region. The north-eastern and southern regions have been suffering from depopulation and ageing since long (Daugirdas et al. 2013). However, both regions become 'lively' in the summer as they are surrounded by lakes and woods, and thus city residents go to rest there and

Regional Statistics, Vol. 8. No. 2. 2018:46-68; DOI: 10.15196/RS080203 
own homesteads as weekend or summer houses. Based on current tendencies, it is likely that the north-eastern and southern regions will remain attractive; sadly, we cannot be so positive about the Central Lithuanian region, which is a more agricultural area.

\section{Conclusion and discussion}

\section{Concluding remarks}

Depopulation, youth emigration, ageing, the formation of SPTs, and other undesirable demographic phenomena appear in many countries in Europe. The processes look similar superficially, but a deeper look at the causes reveals some differences. In Lithuania, as well as in other CEE countries, the situation is different from that in the developed Western European countries. In western countries, the reasons are more 'traditional': demography and influences from social and urbanisation processes (Burholt-Dobbs 2012, Cawley 1994, Haase et al. 2016). Meanwhile, Lithuania saw a change in residents' values: the economic system created by the Soviet Union is transforming, receding from the agricultural sector that required a lot of manual labour. In addition, the artificial settlement system (Vanagas et al. 2002) is also transforming (reminiscent of 're-naturalisation', Kriaučiūnas et al. 2014). Nowadays, the choice of residence is not restricted; the population migrates and chooses the cities and territories that can provide them with more prosperity and a better quality of life.

Since Lithuania regained its independence, large territorial demographic differences have emerged, indicating the creation of two 'demographic Lithuanias'. The capital Vilnius and its surroundings, as well as the other major cities of Kaunas and Klaipéda with their suburban areas, stand as strong growing centres, while the rest of the country is experiencing the opposite developmental tendencies and their population is rapidly shrinking. Our data analysis and previous studies (e.g. Daugirdas et al. 2013, Pociūté 2014) reveal great demographic differences. North-Eastern and Southern Lithuania has depopulated mostly due to a negative birth rate and the demographic situation. These regions might be considered substandard and have been so for decades. We might consider the demographic situation in Western Lithuania as rapidly deteriorating. For some time, this region had a better population composition according to age, it did not have such a fast ageing process, and it had a high number of younger people. Therefore, we see currently high emigration indicators in this region, mostly of younger population, while there is no one to emigrate from North-Eastern Lithuania.

We emphasise two research dimensions because we believe that demographic and socioeconomic indicators are the cornerstone showing how well the country stands in the national and international arena. Both these dimensions highly

Regional Statistics, Vol. 8. No. 2. 2018: 46-68; DOI: 10.15196/RS080203 
correlate with and influence each other. For example, the disappearance of the network of education and other social service institutions follows depopulation in Lithuania (Kriaučiūnas et al. 2014). While analysing the data, we find 'closed circles'; for example, ongoing depopulation influences the collapse of social infrastructure, and because of the loss of infrastructure, depopulation continues. This circle eliminates the possibility of improving the demographic situation. In addition, we see that the decreasing number of work places influences depopulation (usually emigration); but due to the absence of workforce, companies are not interested in locating in rural regions. Again, this leads residents to migrate from villages or towns out of the region. These examples illustrate the tight relations between demographic changes and socioeconomic underdevelopment.

\section{Future research}

So far, there are no existing demographic preconditions for the improvement of the situation or a change in tendencies. We must understand that depopulation will continue: villages and smaller cities will become less populated. This process is inevitable and natural in the era of globalisation. There is no reason to expect that the wooded or infertile peripheral regions will exhibit population growth in the near future. The sharpest result of depopulation is the decline of the social network, which increases residents' social and territorial exclusion. This means that the institutions are receding from the residents of SPRs. People need to travel further to schools, medical institutions, post offices, shops, and other institutions. This tendency has been particularly sharp since 2004, when Lithuania joined the EU. On the other hand, there is no reason to encourage population growth in SPTs. Knowing the situation in these territories, we can say that no efforts can reverse the current trends in these territories. The emigration of part of the population has already cut off a large part of the potentially reproductive population, and this 'hole' will become even deeper due to the long-term low fertility rate. The age structure is unfavourable for reproduction, as Lithuania is the most rapidly ageing and depopulating country in the EU. There will be an increasing number of people of retirement age, and they will live longer. This is the most serious social and economic challenge for the country.

We can expect re-emigration and immigration, especially if the living standards reach the western European standards. Lithuania is suitable for habitation. We believe that eventually SPTs will be highly valued - and they already are. Often, SPTs are located in or very close to protected areas of Lithuania. Therefore, these territories are characterised by high forest cover and beautiful landscapes, and they are full of lakes and have special historical value. Additionally, SPTs are very calm and beautifully maintained. The environment was improved using mostly EU funds; thus, in the municipalities of SPTs, we find renovated schools and cultural centres. The residents of these settlements are gathering into communities

Regional Statistics, Vol. 8. No. 2. 2018:46-68; DOI: 10.15196/RS080203 
and working for their homeland. SPTs provide excellent conditions for living and for recreation and tourism.

We should look ahead and continue to develop infrastructure and improve living conditions in rural territories and small cities, but the improvements must be rational. The government's regional strategies (e.g. the most recent 'Lithuanian Regional Policy White Paper', National Regional Development Council [2017]) should be less general and more place-specific. We support the ideas of Dax and Fischer (2018, p. 306.), who state that there is a great need for a regional policy to make a '...shift towards improving well-being and local attractiveness for the remaining population.' However, this does not mean that the improvement should occur by investing EU funds in rural institutions that will shortly be closed just to create a better 'panorama' of the village; we should rather think about improving the legal basis that would become the guidelines for regional policy.

Our research motivates us to think about the (system of) indicators that could best define the quality of life in the Lithuanian territories, especially in the problematic ones (such as SPTs). In general, we can study quality of life via qualitative and quantitative indicators. The qualitative part (completed with semistructured interviews) in our project is left for sociological research, while we aimed to find the most suitable quantitative indicators to evaluate the topic. The selection of indicators to measure quality of life is a very subjective issue; therefore, the question 'What is the best way to evaluate quality of life quantitatively and underline the increasing territorial exclusion?' is still open for discussion.

\section{Acknowledgement}

This article is based on a report presented at the international conference in Poland, 'Warsaw Regional Forum 2017: Space of Flows' (Warsaw, 18-20 October 2017). The research was funded by a grant from the Research Council of Lithuania ('Regional disparities of welfare in Lithuania' Project, No. GER-005/2017). The authors thank Viktorija Baranauskiené and Aušra Baranauskaité from the Lithuanian Social Research Centre for their help with the graphics.

\section{REFERENCES}

ADE (2012): Study on the relevance and the effectiveness of ERDF and Cohesion Fund support to Regions with Specific Geographical Features - Islands, Mountainous and Sparsely Populated areas Final Report Vol.1. http://ec.europa.eu/ regional_policy/sources/docgener/evaluation/pdf/eval2007/geographical_final 1.pdf (downloaded: 21 February 2018).

AMCOFF, J.-WESTHOLM, E. (2007): Understanding rural change - demography as a key to the future Futures 39 (4): 363-379. http://dx.doi.org/10.1016/j.futures.2006.08.009

Bernt, M.-COCKS, M.-COUCH, CH.-GrossmanN, K.-HAASE, A.-RINK, D. (2012): Shrink Smart The Governance of Shrinkage within a European Context Policy Response

Regional Statistics, Vol. 8. No. 2. 2018: 46-68; DOI: 10.15196/RS080203 
Governance and Future Directions Brief No. 2. Helmholtz Centre for Environmental Research UFZ, Leipzig. http://www.ufz.de/export/data/ 400/39031_ResearchBrief2_.pdf (downloaded: 29 March 2018).

BurHOL, V.-DOBBS, C. (2012): Research on rural ageing: where have we got to and where are we going in Europe? Journal of Rural Studies 28 (4): 432-446. https://doi.org/10.1016/j.jrurstud.2012.01.009

BURNEIKA, D. (2012): Transformations in Lithuania - factors of change and regional patterns In: GorZelaK, G.-GOH, C. C.-FAZEKAS, K. (eds.). Adaptability and Change: The Regional Dimensions in Central and Eastern Europe pp. 267-283., Poligraf, Drelow.

Burneika， D.-UbarevičIEnÉ， R.-VAlatka， V.-BARAnauskaité， A.-PociūtéSEREIKIENE, G.-DAugirdas, V.-KRuPICKAITÉ, D. (2017): Lietuvos metropoliniai regionai. Gyventoju erdviné diferenciacija XXI a.pradžioje Lietuvos socialinių tyrimų centras, Vilnius.

CAWLEY, M. E. (1994): Desertification: measuring population decline in rural Ireland Journal of Rural Studies 10 (4): 395-407. https://doi.org/10.1016/0743-0167(94)90049-3

Churski, P.-BurneikA, D.-Korec, P. (2014): Areas of economic growth and areas of stagnation as objects of special intervention in the regional policies: an international comparison In: CHURSKI, P. (ed.). The social and economic growth vs. the emergence of economic growth and stagnation areas pp.151-188., Bogucki Wydawnictwo Naukowe, Poznan.

Copus, A. K. (2001): From core-periphery to polycentric development: Concepts of spatial and aspatial peripherality European Planning Studies 9 (4): 539-552. https://doi.org/10.1080/713666491

Copus, A. K.-Courtney, P.-Dax, T.-Meredith, D.-Noguera, J.-Shucksmith, M.TALBOT, H. (2011): EDORA-European development opportunities for rural areas Final Report ESPON, Luxembourg. https://www.espon.eu/ main/Menu_Projects/Menu_ESPON2013Projects/Menu_AppliedResearch/ed ora.html (downloaded: 25 March 2018).

Copus, A.-DAx, T. (2010). Conceptual background and priorities of European Rural Development Policy Deliverable 1.2, EU project FP7: Assessing the impact of rural development policies' RuDI, Stockholm.

Daugirdas, V.-Burneika, D.-Kriaučiūnas, E.-Ribokas, G.-STANAitis, S.UBAREVIČIENÉ, R. (2013): Lietuvos retai apgyventos teritorijos Lietuvos socialinių tyrimu centras, Vilnius.

DAX, T.-FISCHER, M. (2018): An alternative policy approach to rural development in regions facing population decline European Planning Studies 26 (2): 297-315. https://doi.org/10.1080/09654313.2017.1361596.

Escalona-Orcao, A. I.-DíEz-Cornago, C. (2007): Accessibility to basic services in one of the most sparsely populated areas in Europe: the province of Teruel (Spain) Area 39 (3): 295-309. https://doi.org/10.1111/j.1475-4762.2007.00749.x.

EUROPEAN COMMISSION (2004): Third report on economic and social cohesion EC, Brussels. http://ec.europa.eu/regional_policy/sources/docoffic/official/reports /pdf/cohesion3/cohesion3_part1_terr_en.pdf (downloaded: 21-02-2018).

Regional Statistics, Vol. 8. No. 2. 2018:46-68; DOI: 10.15196/RS080203 
Gløersen, E.-Dubois, A.-Copus, A.-Schürmann, C. (2006): Northern Peripheral, Sparsely Populated Regions in the European Union and in Norway Nordregio report, Stockholm. http://www.nordregio.se/en/Publications/Publications-2006/NorthernPeripheral-Sparsely-Populated-Regions-in-the-European-Union-and-in-Norway/ (downloaded: 21-02-2018).

Gløersen, E.-Dubois, A.-Roto, J.-Rasmussen, R. O.-Sterling, J. (2009): Development perspectives for the NSPA: Opportunities and Challenges Working Paper Nordregio, Stockholm. http://www.nordregio.se/en/ Publications/Publications-2009/Development-perspectives-for-the-NSPA/ (downloaded: 21-02-2018).

Gløersen, E.-Dubois, A.-SChürmann, C. C. A. (2005): Northern Peripheral, Sparsely Populated Regions in the European Union Nordregio report, Stockholm. https://www.diva-portal.org/smash/get/diva2:700435/FULLTEXT01.pdf (downloaded: 21-02-2018).

Gutiérrez, J.-Urbano, P. (1996): Accessibility in the European Union: the impact of the Trans European road network Journal of Transport Geography 4 (1): 15-25. https://doi.org/10.1016/0966-6923(95)00042-9.

HaAse, A.-Bernt, M.-Grossmann, K.-MykhnenkO, V.-RinK, D. (2016): Varieties of shrinkage in European cities European Urban and Regional Studies 23 (1): 86-102. https://doi.org/10.1177/0969776413481985.

HaAse, A.-RinK, D.-Grossmann M. B.-MYKhnenKO, V. (2014): Conceptualizing Urban Shrinkage Environment and Planning A. 46 (7): 1519-1534. https://doi.org/10.1068/a46269.

Ilcsikné MAKRA, Zs.-BAjMócy, P.-BAlogh, A. (2018): Villages on the Edge of Extinction - the Hungarian Situation Journal of Settlements and Spatial Planning 9 (1): 35-45. https://doi.org/10.24193/JSSP.2018.1.04.

JANC, K. (2006): Human and social capital in Poland - spatial diversity and relations In: Komornicki, T.-Czapiewski, K. (eds.): Core and peripheral regions in Central and Eastern Europe pp. 39-55. EUROPA XXI, 14, PTG, IGiPZ PAN, Warszawa.

Jauhiainen, J. S. (2000): Regional Development and Regional Policy European Union and the Baltic Sea Region Turku University, Turku.

KovÁcs, P.-BODNÁR, G: (2017): Examining the Factors of Endogenous Development in Hungarian Rural Areas by Means of PLS Path Analysis Regional Statistics 7 (1): 090-114. https://doi.org/10.15196/RS07106.

KRIAUČIŪNAS, E. (2010): Some development patterns of Lithuanian rural territories in 1990-2010 Geopolitical Studies 16: 199-212.

Kriaučiūnas, E.-Krupickaité, D.-Pociūté-SEREIKIENĖ, G.-UbarevičIEnÉ, R. (2014): Lietuvos kaimo gyvenviečių funkciju kaitos regioninés ypatybés Geografijos Metraštis 47: 70-87.

Krisjane, Z. (2001): New Trends in the Development of small Towns in Latvia Geografiski Raksti 9: 33-47.

KÜHN, M. (2013): Peripheralization: Theoretical concepts explaining socio-spatial inequalities. European Planning Studies 23 (2): 367-378. https://doi.org/10.1080/09654313.2013.862518.

Regional Statistics, Vol. 8. No. 2. 2018: 46-68; DOI: 10.15196/RS080203 
KÜHN, M.-BERNT, M. (2013): Peripheralization and power In: FISCHER-TAHIR, A.Naumann, M. (eds.): Peripheralization: The making of spatial dependencies and social injustice pp. 302-317., Springer, Wiesbaden.

Kulcsár, L. J.-Brown, D. L. (2017): Population Ageing in Eastern Europe: Toward a Coupled Micro-Macro Framework Regional Statistics 7 (1): 115-134. https://doi.org/10.15196/RS07107.

LANG, T. (2015): Socio-economic and political responses to regional polarisation and sociospatial peripheralisation in Central and Eastern Europe: A research agenda Hungarian Geographical Bulletin 64 (3): 171-185. https://doi.org/10.15201/hungeobull.64.3.2.

LEICK, B.-LANG, T. (2018): Re-thinking non-core regions: planning strategies and practices beyond growth European Planning Studies $26 \quad$ (2): 213-228. https://doi.org/10.1080/09654313.2017.1363398.

Marada, M.-ChromÝ, P.-JAnČÁK, V.-HavlíčEK, T. (2006): Space polarization and peripheral regions in Czechia Europa XXI 15: 29-34.

Margaras, V. (2016): Sparsely populated and under-populated areas Briefing, European Parliament.

http://www.europarl.europa.eu/RegData/etudes/BRIE/2016/586632/EPRS_ BRI(2016)586632_EN.pdf (downloaded: 21 February 2018).

MisıŪNAS, A.-SvETIKAS, Ž. (2003): Lietuvos regionų ekonomikos netolygumų vertinimai Ekonomika 64: 84-94. http://etalpykla.lituanistikadb.lt/fedora/objects/LT-LDB0001:J.04 2003 1367179614454/datastreams/DS.002.0.01.ARTIC/content.

Mladenov, CH.-Ilieva, M. (2012): The depopulation of the Bulgarian villages Bulletin of Geography. Socio-economic Series 17 (17): 99-107. https://doi.org/10.2478/ v10089-012-0010-8.

NAGY, E.-NAGY, G.-DudÁs, G. (2016): The uneven transformation of consumption spaces and the rise of new marginalities in Hungary Regional Statistics 6 (2): 149-172. https://doi.org/10.15196/RS06208.

NAgY, G. (2005): Changes in the Position of Hungarian Regions in the Country's Economic Field of Gravity In: BARTA, G.-G FEKETE, E. et al. (eds.) Hungarian Spaces and Places: Patterns of Transition pp. 124-143. HAS. Centre for Regional Studies, Pecs.

NAgY, G. (2010): Tertiarisation - a global process with local specialities in a new member country (Hungary) In: CAMACHO BALlesta, J. A.-RubalCABA, L. -BRYSON, J. R. (eds.) The Dynamics of Outsourcing and Offshoring Services: Economic and Organisational Challenges. New Trends in the Spatial Location of Services Part II. Chapter 9. Edward Elgar Publishing, Cheltenham.

National Regional Development Council (2017): Lithuanian Regional Policy White Paper https://vrm.lrv.lt/uploads/vrm/documents/files/ENG_versija/Lithuanian\%20 Regional\%20Policy\%20(White\%20Paper).pdf (downloaded 12 February 2018).

Nemes Nagy, J.-TAgAI, G. (2011): Regional inequalities and the determination of spatial structure Regional Statistics 1 (1): 149-172.

NORTHERN SPARSELY POPULATED AREAS NSPA (2009): NSPA vision report http://www.nspa-network.eu/media/3412/nspa \%20vision\%20report\%20\%2015-09-2009\%5B1\%5D.pdf (downloaded: 25 June 2013).

Regional Statistics, Vol. 8. No. 2. 2018:46-68; DOI: 10.15196/RS080203 
Philipov, D.-Kohler, H. P. (2001): Tempo Effects in the Fertility Decline in Eastern Europe: Evidence from Bulgaria, the Czech Republic, Hungary, Poland, and Russia European Journal of Population 17 (1): 37-60. https://doi.org/ 10.1023/A:1010740213453.

Pociūté, G. (2014): Peiferingumo teritoriné raiška Lietuvoje Vilnius University, Vilnius. http:/ /vddb.library.lt/ fedora/get/LT-eLABa-

0001:E.02 2014 D_20140512_103814-60982/DS.005.0.01.ETD (downloaded: 12 February 2018).

Pociūté-Sereikiené，G.-Kriačiūnas，E.-UbareviČIEné，R. (2014): Peripheralisation trends in rural territories: the case of Lithuania Studies in Agricultural Economics 116: 122-130. http://dx.doi.org/10.7896/j.1421.

RAAGMAA, G. (1996): Shifts in regional development of Estonia during the transition European Planning Studies 4 (6): 683-703. http://dx.doi.org/10.1080/ 09654319608720374.

RAagmaA, G. (2003): Centre-periphery model explaining the regional development of informational and transitional society. Paper presented at the 43rd Congress of the European Regional Science Association, 27-30 August 2003. Jyväskylä, Finland.

SiPAVIČIENÉ, A.-STANKŪNIENÉ, V. (2013): The social and economic impact of emigration on Lithuania Coping with Emigration in Baltic and East European Countries pp. 45-64., OECD, Paris. http://dx.doi.org/10.1787/9789264204928-en.

SMETKOWSKI, M. (2018): The role of exogenous and endogenous factors in the growth of regions in Central and Eastern Europe: the metropolitan/non-metropolitan divide in the pre- and post-crisis era European Planning Studies 26 (2): 256-278. https://doi.org/10.1080/09654313.2017.1361585.

Sobotka, T.-Zeman, K.-Kantorová, V. (2003): Demographic Shifts in the Czech Republic after 1989: A second Demographic Transition View European Journal of Population 19 (3): 249-260. https://doi.org/10.1023/A:1024913321935.

StANKŪNIENÉ, V.-SiPAVIČIEnÉ A.-JASIlIOnIS, D. (2012): Demografiniai pokyčiai ekonominiu nestabilumu kontekste Lietuvos socialiné raida. Lietuvos socialiné raida ekonomikos nuosmukio salygomis 1: 23-53.

UbAREviČIENÉ, R.-VAN HAM, M. (2017): Population decline in Lithuania: who lives in declining regions and who leaves? Regional Studies, Regional Science 4 (1): 57-79. https://doi.org/10.1080/21681376.2017.1313127.

VAISHAR, A. (2006): Regional periphery: What does it mean? Europa XXI 15: 7-12.

VANAGAS, J.-KRiŠjĀNE, Z.-NOORKOIV, R.-STANIUNAS, J. (2002): Planning urban systems in Soviet times and in the era of transition: the case of Estonia, Latvia and Lithuania Geographia Polonica 75 (2): 75-100.

ZASADA, I.-LOIBL W.-KOESTL, M.-PIORR, A. (2013): Agriculture under human influence: a spatial anglysis of farming systems and land use in European rural-urban-regions European Countryside 5 (1): 71-88. https://doi.org/10.2478/euco-2013-0005.

Regional Statistics, Vol. 8. No. 2. 2018: 46-68; DOI: 10.15196/RS080203 


\section{WEB REFERENCES}

Eurostat DATABASE (2018): Database of indicators http://ec.europa.eu/eurostat/ web/population-demography-migration-projections/population-data (downloaded: 12 February 2018).

LR VYRIAUSYBÉS (2003): Dél probleminiu teritoriju išskyrimo kriteriju“ Act. Nr. 35-1483.

STATISTICS LiTHUANIA (2017): Database of indicators https://osp.stat.gov.lt/statistiniurodikliu-analize\# (downloaded: 11 September 2017).

STATISTICS LiTHUANIA (2018): Database of indicators https://osp.stat.gov.lt/statistiniurodikliu-analize\# (downloaded: 11 January 2018) 